\title{
Use of Solid Timber Waste as Potential Raw Material for Novel Herbal Drugs: Multidisciplinary Research, Development, and Innovation
}

\author{
Luciana Jankowsky ${ }^{1,2,3 *}$, Brito J0 ${ }^{4}$, Jankowsky $\mathrm{IP}^{1}$, Nolasco $\mathrm{AM}^{1}$ and Carvalho $\mathrm{JE}^{2,3}$ \\ ${ }^{1}$ Department of Forest Products, University of Agriculture Luiz de Queiroz and University of São Paulo, Brazil \\ ${ }^{2}$ Department of Pharmacology and Toxicology, Pluridisciplinary Center for Chemical, Biological and Agricultural Research and Estate University of \\ Campinas, Brazil \\ ${ }^{3}$ Department of Structural and Functional Biology, Estate University of Campinas, Brazil \\ ${ }^{4}$ Forestry Science and Research Institute, Brazil
}

*Corresponding author: Luciana Jankowsky, Department of Forest Products, University of Agriculture Luiz de Queiroz and University of São Paulo, 11 Padua Dias Avenue, Piracicaba, São Paulo, Brazil

Submission: 㘹August 12 , 2017; Published: 眥 October 23, 2017

\begin{abstract}
Solid timber waste obtained from wood industries contains chemical compounds that may be used in phytochemical and pharmacological studies, and possess great potential for use in drug discovery. For its use as a raw material by the pharmaceutical, cosmeceutical, and veterinary industries, multidisciplinary studies and planning are needed. In this study, the wood of 3 trees, Dipteryx odorata (Aubl.) Willd. (Fabaceae), Bowdichia nitida (Spr.) Benth (Fabaceae) and Myroxylon balsamum (L.) Harms (Fabaceae), was selected for phytochemical and pharmacological studies to evaluate antiproliferative activities in human tumor cells. The results obtained demonstrated the potential of solid wood residue a source of raw material for the discovery of pharmacologically active compounds. This source has been poorly explored, considering that it holds tremendous potential for the development of novel herbal drugs. However, it is necessary to implement a National Solid Waste Policy, proposing rules to improve management, classification and collection of solid waste generated by lumber based industries; which could allow a safe use of wood residues in phytochemical and pharmacological studies. The extracts studied demonstrate the potential to add value to non-timber forest products.
\end{abstract}

Keywords: Herbal medicine; Solid timber waste; Photochemistry; Antiproliferative assay; Dipteryx odorata; Bowdichia nitida; Myroxylon balsamum; Non-timber forest products; National Solid Waste Policy

Abbreviations: NTFPs: Non Timber Forest Products; DCE: Dichloromethane Crude Extract; ECE,: Ethanolic Crude Extract; RPMI: Roswell Park Memorial Institute; FBS: Fetal Bovine Serum; DMSO, Dimethyl Sulfoxide; CAPES: Coordination for the Improvement of Higher Education Personnel

\section{Introduction}

All plant material is chemically composed of secondary metabolites that hold potential to be developed into semi synthetic or synthetic herbal drugs. Study of archaeobotanical and ethnobotanical history reveals that medicinal plants have been used in the treatment of diseases by ancient civilizations; both western and eastern cultures are now replete with such examples [1-3]. This knowledge on the use of medicinal plants has been passed down from generation to generation until the emergence of modern concepts, such as ethnobotany, ethnopharmacology, pharmacognosy, and pharmacology.

Different parts of plants, such as leaves, bark, flowers, and roots, are commonly used to evaluate phytochemical and pharmacological activities $[4,5]$. However, timber from trees can also be used for the isolation of chemical compounds with potential pharmacological applications. Wood industries are plant-based, and therefore, solid waste generated by them is basically composed of holocellulose, lignin, and extractives that are water-soluble (phenolic compounds, carbohydrates, and nitrogen compounds) or water-insoluble (terpenes and their derivatives) [6,7]. However, the potential pharmacological activities of these extractives, derived from the secondary metabolism in plants, remain largely unexplored [8-10].

As per the current policy (number 12.651, from 2012), wood from trees grown in Brazilian forests is to be used in civil construction and flooring industries. Non-timber forest products (NTFPs), such as fruits, oils, and resins, for ornamental or medicinal use are poorly managed. All vegetal materials contain chemical compounds that hold potential to be developed into semisynthetic or synthetic phytotherapeutic and heral drugs, thereby making research on NTFPs worthwhile and necessary [9].

The biological diversity campaign conducted in 1992 (Rio-92) focused on several aspects of the legal exploitation of biological diversity, including the use of wood and NTFPs [11]. Brazilian 
forests host $19-20 \%$ of the biodiversity worldwide [12,13], and the Brazilian rainforest provides an attractive avenue for the discovery of new pharmaceutical drugs $[2,14]$. In this study, we used solid waste of 3 plant species, Dipteryx odorata (Aubl) Willd (Fabaceae), Bowdichia nitida (Spr.) Benth (Fabaceae) \& Myroxylon balsamum (L.) Harms (Fabaceae), for bioguided phytochemical and pharmacological analyses, to investigate their possible antiproliferative activities in human tumor cell lines.

\section{Materials and Methods}

\section{Obtaining the timber material}

Discarded timber belonging to 3 woody species was obtained for phytochemical analyses from the wood flooring industry, Indus parquet Ltda. (Tietê, São Paulo). Only large solid timber waste that is discarded during the production of wooden flooring was used.

\section{Identification of the timber samples}

Macroscopic identification of the samples based on anatomy was performed by Professor Dr. João Perez Chimelo.

\section{Preparation of the timber samples}

Organic solvents used in this study were obtained from Merck (Sigma-Aldrich, São Paulo-Brasil). The previously identified and separated timber samples were processed by the Forestry Engineering Faculty, department of forest products (ESALQ/USP) and milled in a Wiley mill (mesh 10). The samples were subjected to Soxhlet extraction, initially with dichloromethane (a medium polarity organic solvent) yielding the dichloromethane crude extract (CDE), and later with absolute ethanol (a polar organic solvent) providing the ethanolic crude extract (EC. Solvents were evaporated from the DCE at $40{ }^{\circ} \mathrm{C}$ and from the ECE at $50{ }^{\circ} \mathrm{C}$ in a rotary evaporator, after which both the extracts were lyophilized.

\section{Antiproliferative assay on human tumor cell lines}

The antiproliferative effects of the crude extracts of the 3timber species were investigated [15]. A panel of 9 human tumor cell lines: MCF-7 (breast cancer), NCI-ADR/RES (ovarian cancer cells expressing a multiple drug resistance phenotype), 786-0 (renal carcinoma), NCI-H460 (non-small cell lung cancer), PC-3 (prostate cancer), OVCAR-03 (ovarian cancer), HT-29 (colon adenocarcinoma), UACC-62 (melanoma), and K-562 (chronic myeloid leukemia), provided by the Frederick Cancer Research \& Development Center, National Cancer Institute, Frederick, MA, USA were used. Stock and experimental cultures were maintained in $5 \mathrm{~mL}$ of Roswell Park Memorial Institute-1640 buffer supplemented with $5 \%$ fetal bovine serum (RPMI/FBS 5\%) with penicillin (1000 $\mathrm{U} / \mathrm{mL})$-streptomycin $(1000 \mu \mathrm{g} / \mathrm{mL})$ mixture $(1 \mathrm{~mL} / \mathrm{L}$ of RPMI1640).

Stock solutions of the samples (5mg) were prepared in dimethyl sulfoxide (DMSO, $50 \mu \mathrm{L}$ ) followed by serial dilutions in RPMI/FBS $5 \%$ to give final concentrations of $0.25,2.5,25$, and $250 \mu \mathrm{g} / \mathrm{mL}$. Doxorubicin was used as a positive control at the same concentrations. Cells seeded in 96 -well plates $(100 \mu \mathrm{L} /$ well, $3-7 \times 10^{4}$ cells $/ \mathrm{mL}$ ) were incubated, with each of the 4 concentrations of sample solution or doxorubicin $(100 \mu \mathrm{L} /$ well) in triplicate $(\mathrm{n}=$ 3), for $48 \mathrm{~h}$ at $37{ }^{\circ} \mathrm{C}$ and $5 \% \mathrm{CO}_{2}$. Before (T0 plate) and after (T1 plates) sample addition, cells were fixed with $50 \%$ trichloroacetic acid $(50 \mu \mathrm{L} /$ well) and stained with sulforhodamine B to quantify cell proliferation based on the absorption values obtained using the Molecular Devices Versa Max Microplate Reader at 540nm. The Origin 8.0 software (Origin Lab Corporation) was used to evaluate the cytotoxic activity of the extracts. Samples were considered to possess antitumor activity when growth inhibition $>50 \%$ and concentration-dependent cell-type selectivity was observed.

\section{Results and Discussion}

Phytochemical extraction of the collected timber samples was conducted, and the extracts were assayed for antiproliferative activities in human tumor cells. The in vitro assay results are expressed in terms of the sample concentration $(\mu \mathrm{g} / \mathrm{mL})$ and percentage growth of human tumor cells. A population growth of $<50 \%$ indicated cytostatic action (inhibition of cell growth), whereas that $<0 \%$ (a decline in cell population by cell death) indicated cytocidal activity. Doxorubicin was considered as a positive control for the antiproliferative activity on tumor cells, which exhibited a dose-dependent activity profile. At $2.5 \mu \mathrm{g} / \mathrm{mL}$, it exerted cytostatic activity on kidney, lung, prostate, melanoma, and leukemia cells; at $25 \mu \mathrm{g} / \mathrm{mL}$, it had cytostatic activity on colon, kidney, and ovarian cells, and cytocidal activity on melanoma, leukemia, and prostate cells. At the highest concentration $(250 \mu \mathrm{g} /$ $\mathrm{mL}$ ), it had a cytostatic effect on cells of breast, kidney, and colon and ovarian cells expressing a multiple drug resistance phenotype; it had a cytocidal effect on the remaining cells at this concentration (Figure1).

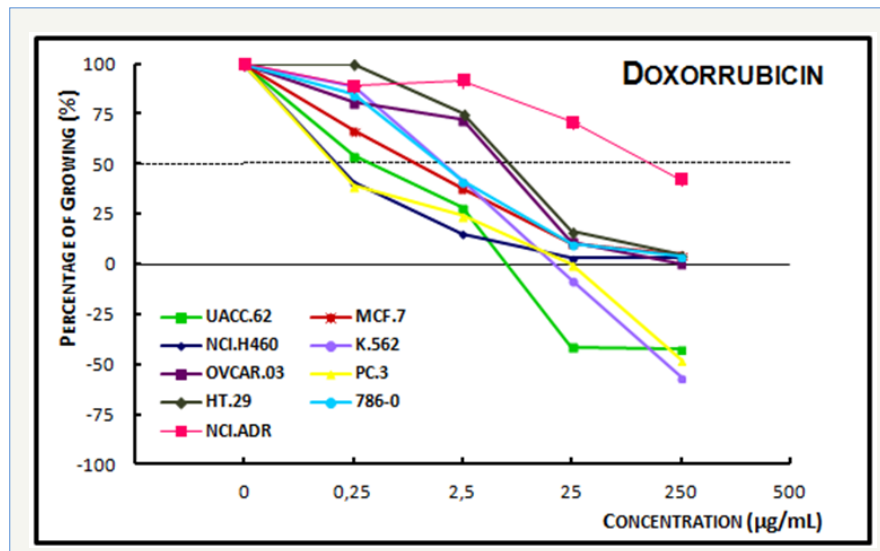

Figure 1: Concentration-response curves of the antiproliferative effects of doxorubicin on various human cell lines, correlating cell growth $(\%)$ and concentration of doxorubicin $(\mu \mathrm{g} / \mathrm{mL})$.

Analysis of the concentration-response curve of the ECE of Dipteryx odorata (Figure 2A) showed a cytotoxic effect on all tumor cell lines at a $250 \mu \mathrm{g} / \mathrm{mL}$, it exhibited cytocidal activity on all the cells, except kidney and multiple drug resistant ovarian concentration of $25 \mu \mathrm{g} / \mathrm{mL}$ at the concentration of cells. At the concentration of $2.5 \mu \mathrm{g} / \mathrm{mL}$, the DCE of Dipteryx odorata (Figure 2B) showed cytotoxic activity only on the ovarian (OVCAR-03) cells, with no significant antiproliferative activity on the remaining cells. At $25 \mu \mathrm{g} / \mathrm{mL}$, a cytocidal effect on leukemia and ovarian cells 
was noted, whereas only cytostatic activity on others cell lines was observed. At $250 \mu \mathrm{g} / \mathrm{mL}$, a cytocidal activity on all cell lines was observed.

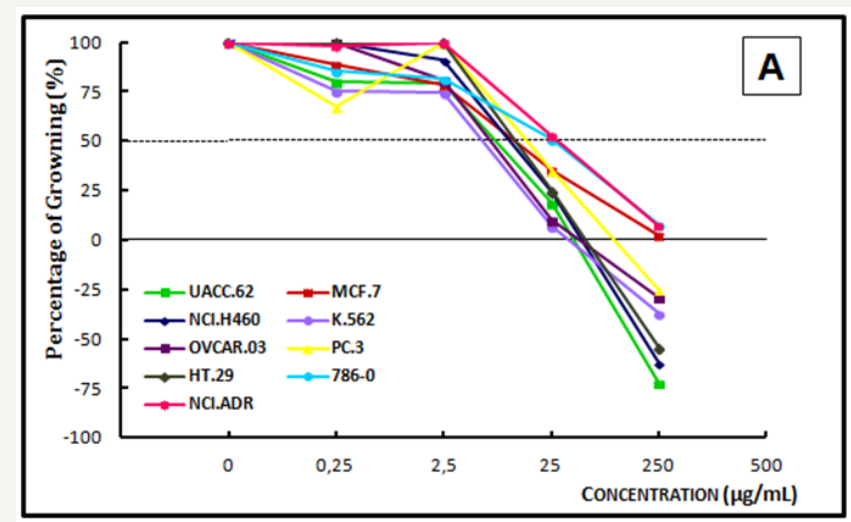

Figure 2A: Concentration-response curves of the in vitro antiproliferative effects of the ethanolic crude extract (ECE).

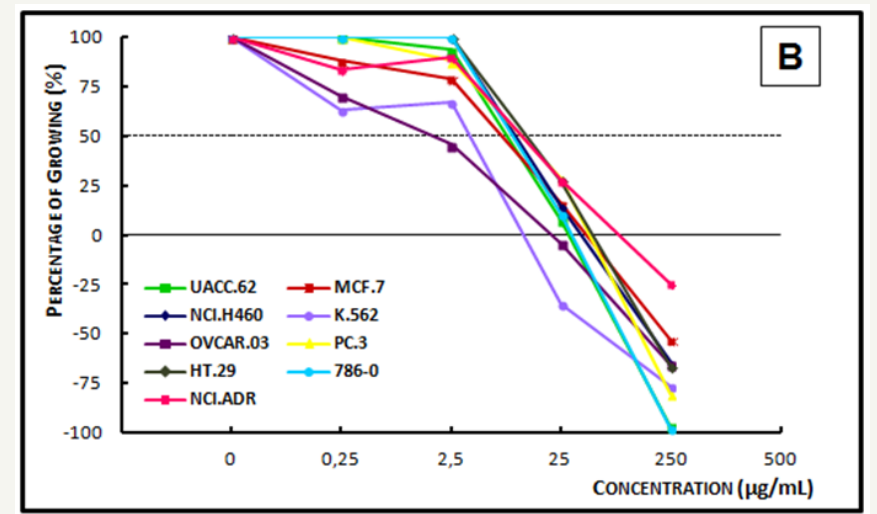

Figure 2B: Concentration-response curves of the in vitro antiproliferative effects of the dichloromethane crude extract (DCE) from the timber of Dypteryx odorata on various human cell lines, correlating cell growth (\%) and concentration of the sample $(\mu \mathrm{g} / \mathrm{mL})$.

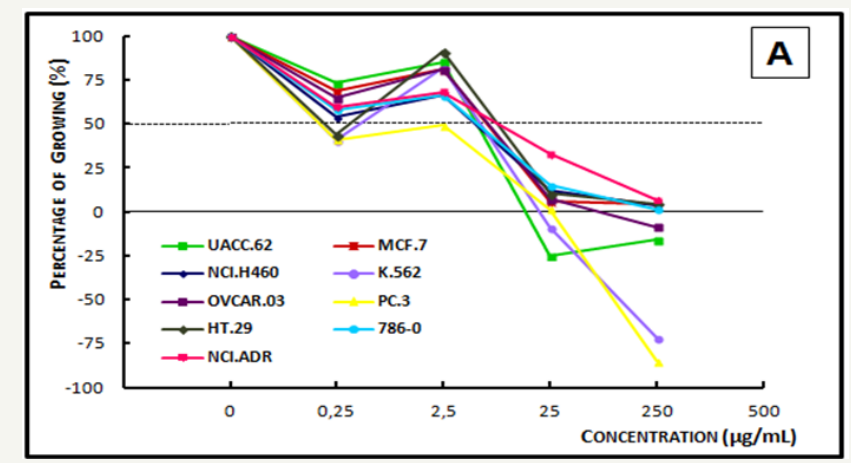

Figure 3A: Concentration-response curve of the in vitro antiproliferative effects of the ethanolic crude extract (ECE).

Analysis of the concentration-response curve of the ECE of Bowdichia nitida (Figure $3 \mathrm{~A}$ ) at $0.25 \mu \mathrm{g} / \mathrm{mL}$, demonstrated a cytostatic activity on prostate, breast, lung, and leukemia cell lines and a cytostatic profile activity only on the prostate cancer cell line. At $2.5 \mu \mathrm{g} / \mathrm{mL}$, the ECE was cytocidal to melanoma, leukemia, and prostate cancer cells; a cytostatic effect was observed on the other cell lines. At $250 \mu \mathrm{g} / \mathrm{mL}$, a cytocidal effect was observed on all cell lines. The DCE of Bowdichia nitida (Figure 3B), at concentrations of $0.25 \mu \mathrm{g} / \mathrm{mL}$ and $2.5 \mu \mathrm{g} / \mathrm{mL}$, a cytostatic activity was observed on leukemia and prostate cancer cells lines. At $25 \mu \mathrm{g} / \mathrm{mL}$, this extract demonstrated cytostatic activity on all but the leukemia cell line, on which it showed a cytocidal action. At $250 \mu \mathrm{g} / \mathrm{mL}$, the extract had a cytocidal profile, as it caused death of all the cells lines.

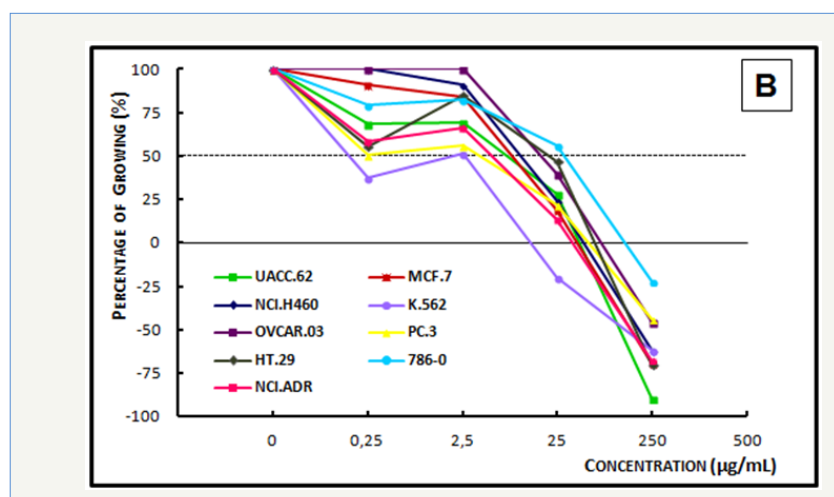

Figure 3B: Concentration-response curve of the in vitro antiproliferative effects of the dichloromethane crude extract (DCE) from the timber of Bowdichia nitida on various human cell lines, correlating cell growth $(\%)$ and concentration of the sample $(\mu \mathrm{g} / \mathrm{mL})$.

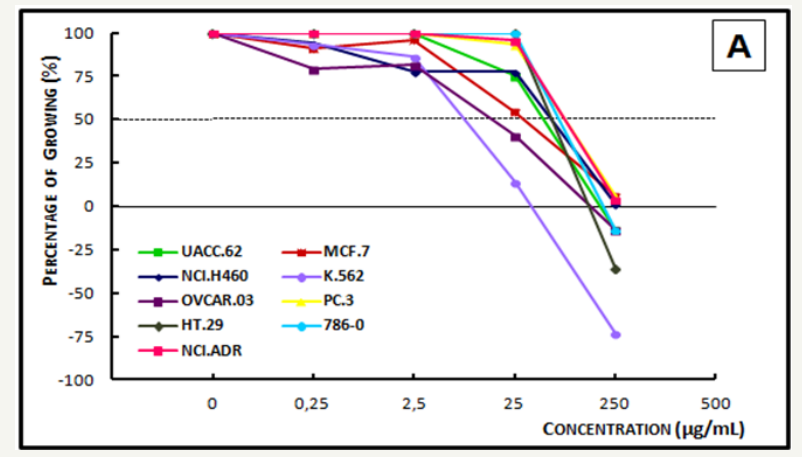

Figure 4A: Concentration-response curve of the in vitro antiproliferative effects of the ethanolic crude extract (ECE).

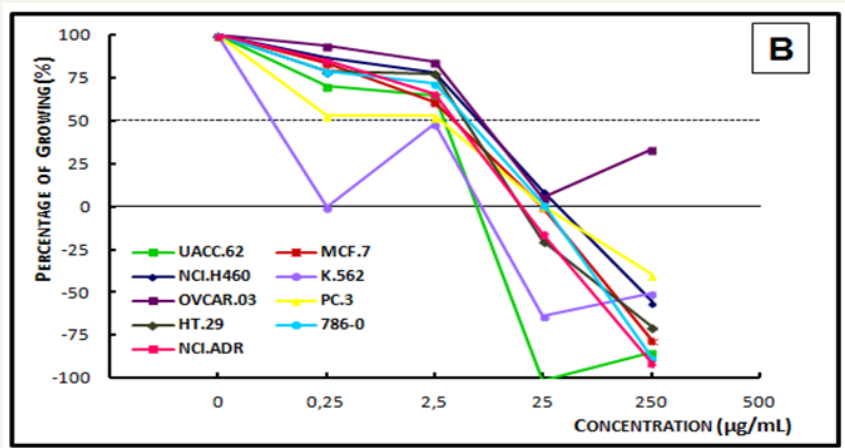

Figure 4B: Concentration-response curve of the in vitro anti proliferative effects of the dichloromethane crude extract (DCE) from the timber of Myroxylon balsamum on various human cell lines, correlating cell growth (\%) and concentration of the sample $(\mu \mathrm{g} / \mathrm{mL})$.

Analysis of the concentration-response curve of the ECE of Myroxylon balsamum (Figure 4A) at the concentration of $25 \mu \mathrm{g} /$ $\mathrm{mL}$ showed cytostatic activity on breast cancer, ovarian cancer, 
and leukemia cells. At $250 \mu \mathrm{g} / \mathrm{mL}$, the extract showed a cytostatic activity on prostate cancer and breast cancer cell lines, and a cytocidal activity on all the other cell lines. The DCE of Myroxylon balsamum (Figure 4B), demonstrated a cytostatic activity at $0.25 \mu \mathrm{g} / \mathrm{mL}$ on the breast cancer cells and at $2.5 \mu \mathrm{g} / \mathrm{mL}$ on leukemia cells; and a cytocidal activity at $25 \mu \mathrm{g} / \mathrm{mL}$ on kidney, lung, prostate, melanoma, breast, leukemia, and multiple drug resistant ovarian cells. In $250 \mu \mathrm{g} / \mathrm{mL}$, it demonstrated a cytostatic activity only on the ovarian cell line and a cytocidal activity on the remaining eight cell lines.

The timber used in this study is a source of several chemical compounds with antitumor potential, as demonstrated by our findings. Moreover, the use of timber discarded during manufacturing of forest products, such as wood used in construction and flooring, presents a significant advantage. It is estimated that approximately 10 million tons of these wastes are discarded annually in Brazil [16]. In this study, only large solid timber waste was used to aid anatomical identification. The majority industries do not have any plans for management of wood waste [17].

Bowdichia nitida, known as sucupira, is widely used in the wood industry. Due to its association with the development of contact allergy, studies on its chemical composition were carried out; the studies revealed the presence of 2,6-dimethoxy-1,4benzoquinone [18]. The ECE of Bowdichia nitida demonstrated cytocidal activity at $25 \mu \mathrm{g} / \mathrm{mL}$ on the prostate cancer, leukemia, and melanoma cell lines. Selectivity for these 3 cell lines justifies further phytochemical and pharmacological studies for the possible isolation and identification of the active principles. Its DCE did not present any significant anticancer activity.

Wood from Dipteryx odorata, popularly known as cumaru, is commonly used in construction and flooring. Its extractives are used in the production of cigarettes, perfumes, and cosmetics [19]. The DCE of this species showed selective cytocidal activity at $25 \mu \mathrm{g} / \mathrm{mL}$ on leukemia and ovarian cancer cell lines. Research reported that flavonoids in its chemical composition contribute to its anticancer activity [19].

Isolation of isoflavanoids, flavanones, and isoflavanones from the trunk and a pentacyclic triterpene from the leaves Myroxylon balsamum has been reported [20]. Results of the antiproliferative activity on tumor cells demonstrated that the DCE exhibited selective cytocidal activity at $25 \mu \mathrm{g} / \mathrm{mL}$ on melanoma, colon, kidney, lung, breast, multiple drug resistant ovarian cancer, and leukemia cells.

However, the optimum use of plants is limited by the following challenges: 1) lack of laws regulating the extraction of plants, either for research or commercial purposes, leading to predatory exploitation and damage to the environment; 2) complexity of chemical structures, making it difficult to synthesize these compounds in the laboratory and elucidate their mechanisms of action; 3) time and cost associated with the isolation and synthesis of, pharmacotechnical processes involved, and preclinical, and clinical studies on the active principle isolated from a plant before its commercialization as a new drug; and 4) the amount of plant material needed to carry out the studies [12].

For solid wood waste to be used as raw material, it must be correctly identified according to the botanical classification of its native species. When obtained from industries as discarded material, collecting and identifying the plant species, based on the anatomy of wood, and cataloging of this process is crucial.

Currently, the National Solid Waste Policy (Policy No. 12,305) in Brazil defines the distinction between solid waste and discards $[17,21]$. According to the policy, timber industries must present a plan for the management of waste, discards, and by-products. Therefore, the use of solid wood waste as a source of raw material for pharmaceutical or cosmeceutical research and development is emphasized [22,23].

\section{Conclusion}

Solid timber residues, due to their chemical composition, are sources poorly explored by the chemical and pharmaceutical industries due the potential for the study of herbal medicine and new drugs. However, it is necessary to implement a National Solid Waste Policy so that solid waste can be managed during the manufacture of logs in the industries, classified and properly collected so that they are safely used in phytochemical and pharmacological studies. The residues studied demonstrate the potential to add value to non-timber forest products.

\section{Acknowledgment}

This study was carried out with the financial assistance of foundation Coordination for the Improvement of Higher Education Personnel (CAPES); the professional assistance of laboratory technique Sirlene Tinti and Reseach Mary Ann Foglio and for Indusparquet Ltda., located in Tietê, São Paulo, for providing the solid waste for study.

\section{References}

1. Leontia M, Stichera O, Heinric M (2003) Antiquity of medicinal plant usage in two Macro-Mayan ethnic groups (México). J Ethnopharmacol 88(2-3): 119-124.

2. Miller JS (2011) The discovery of medicines from plants: A current biological perspective. Economic Botany 65(4): 396-407.

3. Sen S, Chakraborty R (2017) Revival, modernization and integration of Indian traditional herbal medicine in clinical practice: importance, challenges and future. J Tradit Complement Med 7(2): 234-244.

4. Calixto JB (2000) Efficacy, safety, quality control, marketing and regulatory guidelines for herbal medicines (phytotherapeutic agents). Braz J Med Bio Res 33(2): 179-189.

5. Foglio MA, Queiroga CL, Sousa IMO, Rodrigues RAF (2006) Plantas Medicinais como Fonte de Recursos Terapêuticos: Um Modelo Multidisciplinar. MuitiCiência 7: 1-8.

6. Lepage ES (1986) Química da madeira. In: Lepage ES (Ed.), Manual de preservação da madeira. (1 $1^{\text {th }}$ edn), IPT, Brazil, pp. 69-96.

7. Reyes Rivera J, Canché Escamilla G, Soto Hernández M, Terrazas T (2015) Wood chemical composition in species of Cactaceae: the relationship between lignifications and stem morphology PLoS ONE 10(14): e0123919. 
8. Jankowsky L (2005) Atividade farmacológica obtida a partir de resíduos madeireiros, Brazil, pp. 99.

9. Gomes JP, Dacoregio HM, Silva KM, Rosa LH, Bortoluzzi RLC (2017) Myrtaceae na Bacia do Rio Caveiras: Características ecológicas e usos não madeireiros. Floresta e Ambiente (24): e20150111.

10.Jablonsky M, Nosalova J, Sladkova A, Haz A, Kreps F, et al. (2017) Valorisation of softwood bark through extraction of utilizable chemicals A review. Biotechnol Adv 35(6): 726-750.

11. Sánchez LE, Croal P (2012) Environmental impact assessment, from Rio92 to Rio+20 and beyond. Ambiente e Sociedade 15(3): 41-54.

12. Calixto JB (2003) Biodiversidade como fonte de medicamentos. Biodiversidade 55(3): 37-39.

13. Younes RN, Varella AD, Suffredini IB (2007) Discovery of new antitumoral and antibacterial drugs from Brazilian plant extracts using high throughput screening. Clinics 62(6): 763-768.

14.Calixto JB (2005) Twenty-five years of research on medicinal plants in Latin America: a personal view. J Ethnopharmacol 100(1-2): 131-134.

15. Walter AR, Denise BG, Barbara Z, Amanda PS, Kriptsan APD, et al. (2017) Antiproliferative effects of pinostrobin and 5,6-dehydrokavain isolate from leaves of Alpinia zerumbet. Revista Brasileira de Farmacognosia, pp. 1-7.

16. Nolasco AM, Uliana LR (2014) Gerenciamento de resíduos na indústria de pisos de madeira. National Association of Producers of Wood Floors, Brazil, p. 42.
17. (2003) ABINCI Estudo setorial 2003 produtos de madeira sólida, Brazil, p. 68.

18. Hausen BM (1978) Sensitizing capacity of naturally occurring quinones 2.6-dimethoxy-p-benzoquinone: occurrence and significance as a contact allergen. Contact Dermatitis 4(4): 204-213.

19. Jang DS, Park EJ, Hawthorne ME, Vigo JS, Graham JG, et al. (2003) Potential cancer chemopreventive constituents of the seeds of Dipteryx odorata (tonka bean). J Nat Prod 66(5): 583-587.

20. Mathias L, Ivo Vieiraa JC, Raimundo Braz Filhoa, Edson Rodrigues Filhob (2000) A new pentacyclic triterpene isolated from Myroxylon balsamum (syn. Muroxylon peruiferum). Journal of the Brazilian Chemical Society Soc 11(2): 195-198.

21. (2010) Política Nacional de Resíduos Sólidos (PNRS)-Lei $n^{\circ}$ 12.305, Brazil.

22. Iwakini S, Cunha AB , Albuquerque CEC, Gorniak E, Mendes LM (2000) Resíduos de serraria na produção de panéis de madeira aglomerada de Eucalipto. Scientia Agrária 1(1-2): 23-28.

23.Jankowsky IP, Luiz MG, Andrade A (2004) Pisos de madeira maciça: Agregando valor e qualidade ao produto. Encontro brasileiro em madeiras e em estruturas de madeira, Brazil. 